\title{
PENGARUH KONSUMSI MINUMAN MADU HUTAN (Apis dorsata) TERHADAP TINGKAT KEASAMAN PH SALIVA PADA PERAWAT INSTALASI BEDAH SENTRAL (IBS) DI RSUD LABUANG BAJI MAKASSAR
}

\author{
Badai Septa, Surya Irayani, Rini Sitanaya
}

\begin{abstract}
ABSTRAK
Sebelum ditemukannya gula, madu telah digunakan sebagai minuman manis dan sebagai bahan pemberi rasa manis. Madu mengandung glukosa, fruktosa, serta sukrosa. Walaupun madu mengandung sukrosa rendah, madu tetap saja merupakan larutan karbohidrat yang mengandung gula dan dapat menyebabkan $\mathrm{pH}$ saliva menurun. Dalam penelitian ini yang digunakan adalah madu hutan. Penelitian dilaksanakan di RSUD Labuang Baji Makassar. Jumlah sampel dalam penelitian ini sebanyak 25 orang. Penelitian dilaksanakan pada bulan Desember 2019 - Januari 2020. Pengambilan data menggunakan lembar observasi, pH meter dan pembagian Informed Consent. Jenis penelitian yang digunakan adalah Quasi Eksperimen. Penelitian menggunakan rancangan Pretest Posttest Control Group dengan menggunakan teknik Total Sampling. Data diolah dengan menggunakan SPSS dengan analisis Uji T-Test. Rata-rata tingkat keasaman $\mathrm{pH}$ saliva sebelum mengkonsumsi minuman madu hutan adalah 6.99 dan setelah mengkonsumsi minuman madu hutan adalah 6.67 atau mengalami penurunan sebesar 0.32 menjadi lebih asam. Pada uji $\mathrm{T}$ dihasilkan nilai 2.063. Hal tersebut menunjukkan bahwa terdapat perbedaan $\mathrm{pH}$ saliva sebelum dan setelah pemberian minuman madu hutan.
\end{abstract}

Kata Kunci: Apis dorsata, Madu Hutan, pH Saliva

\section{PENDAHULUAN}

Madu telah dikenal oleh manusia sejak abad keempat masehi dan dianggap sebagai bahan pemanis pertama. Sebelum ditemukan gula, madu telah digunakan sebagai minuman manis dan sebagai bahan pemberi rasa manis. Cairan kental dan manis ini juga kerap digunakan sebagai olesan roti. Cairan madu itu sendiri berasal dari lebah madu (Apis mellifera) dan tanaman pada bagian bunga dan pucuk daun. (Republika Online, 2006)

Dalam dunia medis, penggunaan madu sebagai obat sudah dimulai sejak zaman Yunani dan Mesir Purba. Saat itu di Mesir, madu merupakan salah satu dari 500 obat terpopuler. Madu berbeda dengan gula. Madu merupakan food supplement alami yang berkhasiat. Madu mengandung berbagai jenis vitamin, asam amino, macam-macam mineral dan 100 jenis zat yang bermanfaat untuk kesehatan. Karena kandungannya, tak heran jika madu bisa digunakan untuk pengobatan dan suplemen bagi mereka yang tengah berdiet, selain itu, madu juga mengandung monosacharida yang terdiri atas glukosa dan fruktosa, serta sukrosa dengan konsentrasi yang rendah. Oleh karena sukrosa dikenal sebagai sumber penyebab terjadinya karies gigi, sedangkan madu diketahui mengandung sukrosa rendah maka mulai dipikirkan kemungkinan menggunakan bahan alternative yang dapat digunakan sebagai bahan pengganti sukrosa adalah madu.

Walaupun mengandung sukrosa rendah, madu tetap saja merupakan larutan karbohidrat yang mengandung gula dan dapat menyebabkan $\mathrm{pH}$ saliva menurun.

Saliva merupakan faktor yang penting dalam rongga mulut. Saliva mempunyai fungsi fisiologis yaitu membersihkan, pengaruh buffer, melindungi permukaan enamel dan membantu dalam pencernaan karbohidrat. Adanya rangsangan menyebabkan laju aliran saliva meningkatkan sekaligus menyebabkan komponen biokarbonat saliva semakin tinggi dan pada akhirnya akan meningkatkan $\mathrm{pH}$. Akibat dari aliran yang meningkat, hasil-hasil metabolic bakteri, zat-zat toksis bakteri akan larut dan tertelan sehingga keseimbangan lingkungan mulut akan terjaga. (Garant, 2003)

Pada umumnya madu tersusun atas $17,1 \%$ air, $82,4 \%$ karbohidrat total, 0,5\% protein, asam amino, vitamin dan mineral. Selain asam amino nonesensial ada juga asam amino 
esensial di antaranya lysin, histadin, triptofan, dan lain-lain. Karbohidrat yang terkandung dalam madu termasuk tipe karbohidrat sederhana. Karbohidrat tersebut utamanya terdiri dari $38,5 \%$ fruktosa dan $31 \%$ glukosa. Sisanya $12,9 \%$ karbohidrat yang tersusun dari maltosa, sukrosa, dan gula lain. (Intanwidya, 2005)

Hasil penelitian yang dilakukan oleh Cerry Puspa Sari di FKG UI pada tahun 2008, menyatakan bahwa terjadi penurunan pada nilai viskositas, $\mathrm{pH}$ dan kapasitas dapar saliva setelah mengkonsumsi air madu dan air gula sukrosa.

Penelitian mengenai saliva masih belum jauh terungkap, padahal saliva memiliki peran yang cukup penting dalam mempengaruhi terjadinya proses karies. Oleh karena itu penulis tertarik untuk ikut meneliti tentang pengaruh konsumsi minuman madu hutan terhadap tingkat keasaman $\mathrm{pH}$ saliva.

\section{METODE PENELITIAN}

Jenis penelitian yang digunakan adalah penelitian eksperimen semu / quasi experiment. Rancangan penelitian menggunakan rancangan
Pretest Posttest Control Group. Populasi dalam penelitian ini adalah semua perawat Instalasi Bedah Sentral (IBS) di RSUD labuang baji yang bersedia untuk dijadikan sampel penelitian. Sampel dalam penelitian ini berjumlah 25 orang. Sampel dalam penelitian ini diambil menggunakan teknik Total Sampling. Kriteria Inklusi sampel yaitu sampel yang diambil berjenis kelamin laki-laki dan perempuan yang pada saat pemeriksaan tidak sedang berpuasa dan tidak sedang menstruasi untuk sampel berjenis kelamin perempuan. Kriteria Eksklusi sampel yaitu Sampel tidak mengidap penyakit Diabetes mellitus dan tidak memiliki banyak karies. Penelitian ini akan dilaksanakan di RSUD Labuang baji Makassar. Penelitian ini rencananya berlangsung selama dua bulan, dimulai pada bulan Desember 2019 - Januari 2020 .

\section{HASIL PENELITIAN}

1. Karakteristik Responden

Karakteristik responden dalam penelitian ini hanya berupa karakteristik jenis kelamin. Berikut ini adalah distribusi frekuensi responden berdasarkan jenis kelamin:

Tabel 1 Distribusi Karakteristik Responden berdasarkan Jenis Kelamin

\begin{tabular}{|c|c|c|}
\hline Jenis Kelamin & $\mathbf{n}$ & $\%$ \\
\hline Pria & 12 & $48 \%$ \\
\hline Wanita & 13 & $52 \%$ \\
\hline Jumlah & 25 & $100 \%$ \\
\hline
\end{tabular}

Sumber: Data Primer Tahun 2019

Tabel di atas menunjukkan bahwa 52\% responden berjenis kelamin wanita dan $48 \%$ berjenis kelamin pria. Tampak bahwa jumlah responden wanita mendominasi dalam penelitian ini.

Tabel 2 Distribusi Karakteristik Responden berdasarkan Umur

\begin{tabular}{|c|c|c|c|}
\hline Umur & $\mathbf{N}$ & $\%$ & Rata-rata pH saliva \\
\hline $25-42$ & 16 & $64 \%$ & 7,02 \\
\hline $43-60$ & 9 & $36 \%$ & 6,95 \\
\hline Jumlah & 25 & $100 \%$ & \\
\hline
\end{tabular}

Sumber: Data Primer Tahun 2019 
Tabel di atas menunjukkan bahwa responden dengan rentang umur antara 25 - 42 tahun sebanyak 16 orang (64\%) dengan ratarata $\mathrm{pH}$ saliva 7.02 , responden dengan rentang umur antara 43-60 tahun sebanyak 9 orang (36\%.) dengan rata-rata $\mathrm{pH}$ saliva 6.95 .

\section{Analisis Univariat}

Analisis univariat di bawah ini akan membahas distribusi frekuensi responden pada setiap variabel yang diteliti. Analisis univariat yang akan disajikan adalah berupa distribusi frekuensi $\mathrm{pH}$ saliva responden sebelum dan setelah diberikan minuman madu hutan, serta tabel rata-rata $\mathrm{pH}$ saliva responden sebelum dan setelah diberikan minuman madu hutan.

Berikut adalah hasil analisis univariat berupa tabel distribusi frekuensi $\mathrm{pH}$ saliva sebelum dan setelah pemberian minuman madu hutan:

Tabel 3 Distribusi pH Saliva Pada Responden Sebelum Diberi Minuman Madu Hutan

\begin{tabular}{|c|c|c|}
\hline pH saliva & n (Jumlah) & Persentase (\%) \\
\hline Asam & 12 & $48 \%$ \\
\hline Netral & 4 & $16 \%$ \\
\hline Basa & 9 & $36 \%$ \\
\hline Jumlah & $\mathbf{2 5}$ & $\mathbf{1 0 0} \%$ \\
\hline
\end{tabular}

Sumber: Data Primer, tahun 2019

\section{Diagram 3 Distribusi pH Saliva pada Responden Sebelum Diberi Minuman Madu Hutan}

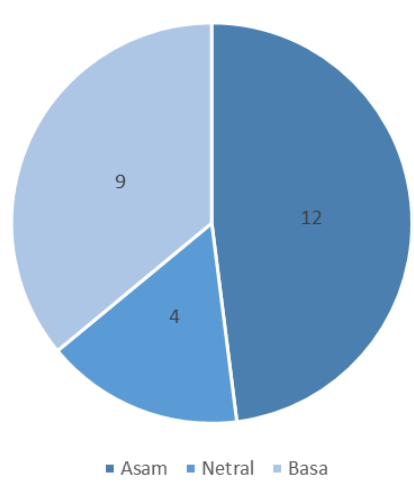

Pada tabel dan diagram 3 menunjukkan bahwa sebelum mengkonsumsi madu hutan sebanyak $12(0.48)$ orang (48\%) responden memiliki pH saliva dengan kriteria asam, 4 (0.16) orang (16\%) responden memiliki $\mathrm{pH}$ saliva dengan kriteria netral, dan 9 (0.36) orang (36\%) responden memiliki $\mathrm{pH}$ saliva dengan kriteria basa. 
Tabel 4 Distribusi pH Saliva Pada Responden Setelah Diberi Minuman Madu Hutan

\begin{tabular}{|c|c|c|}
\hline $\mathbf{p H}$ saliva & $\mathbf{n}$ (Jumlah) & Persentase (\%) \\
\hline Asam & 21 & $84 \%$ \\
\hline Netral & 2 & $8 \%$ \\
\hline Basa & 2 & $8 \%$ \\
\hline Jumlah & $\mathbf{2 5}$ & $\mathbf{1 0 0} \%$ \\
\hline
\end{tabular}

Sumber: Data Primer, tahun 2019

\section{Diagram 4 Distribusi pH Saliva pada Responden Setelah Diberi Minuman Madu Hutan}

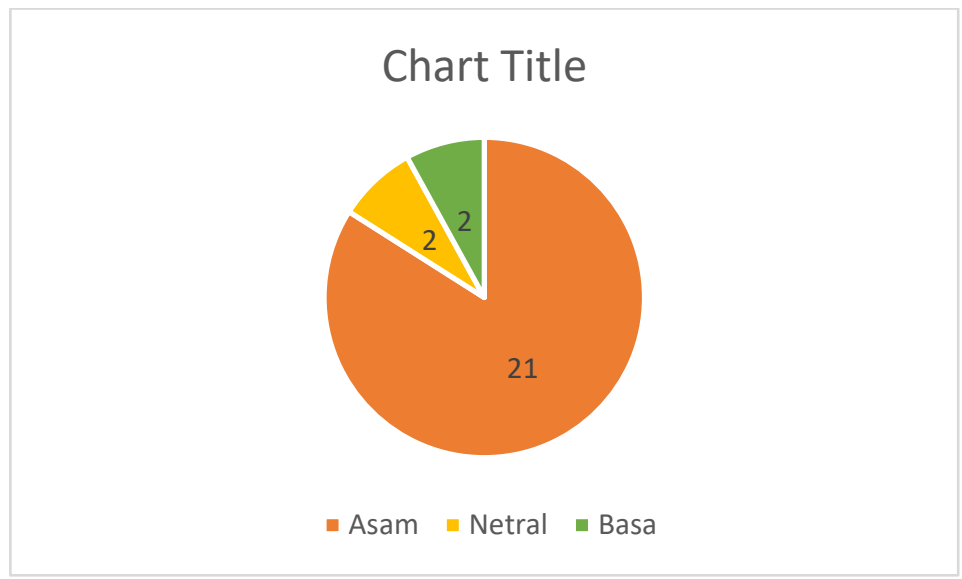

Pada tabel dan diagram 4.4 asam, $2(0.8)$ orang (8\%) responden memiliki pH menunjukkan bahwa setelah mengkonsumsi saliva dengan kriteria netral, dan 2 (0.8) orang madu hutan sebanyak 21 (0.84) orang (84\%) (8\%) responden memiliki $\mathrm{pH}$ saliva dengan responden memiliki $\mathrm{pH}$ saliva dengan kriteria kriteria basa.

Tabel 5 Distribusi Frekuensi Responden Berdasarkan Rata-Rata Nilai pH Saliva

\begin{tabular}{|c|c|c|c|}
\hline \multirow{2}{*}{ Variabel } & \multicolumn{2}{|c|}{ pH Rata-Rata Saliva } & Selisih \\
\cline { 2 - 3 } & Sebelum & Sesudah & \\
\hline $\begin{array}{c}\text { Mengkonsumsi Minuman Madu } \\
\text { Hutan }\end{array}$ & 6.99 & 6.67 & 0.32 \\
\hline
\end{tabular}

Pada tabel di atas nampak bahwa sebelum diberikan minuman madu hutan, ratarata $\mathrm{pH}$ saliva sampel adalah 6.99 dan rata-rata $\mathrm{pH}$ saliva setelah diberikan minuman madu hutan adalah 6.67, dimana terdapat selisih penurunan $\mathrm{pH}$ saliva sebesar 0.32 menjadi lebih asam.

\section{Analisis Bivariat}

Setelah melakukan analisis univariat, kemudian peneliti melakukan analisis bivariat. Uji analisis yang digunakan adalah uji paired- sample $\mathrm{T}$ dimana uji ini berfungsi untuk menganalisis pengaruh pemberian perlakuan pada sampel yang sama. Sampel diberi perlakuan yaitu diberikan minuman madu hutan dimana peneliti melakukan pengukuran $\mathrm{pH}$ saliva sebelum dan setelah pemberian minuman madu hutan.

Hasil uji paired-sample $\mathrm{T}$ pada pengaruh pemberian minuman madu hutan terhadap perubahan $\mathrm{pH}$ saliva menunjukkan nilai Asymp. Sig antara pemberian minuman madu hutan dengan perubahan $\mathrm{pH}$ saliva adalah 
0.053 dimana $0.053>0.05$ dengan $\alpha=0.05$, maka tampak bahwa tidak terdapat pengrauh antara pemberian minuman madu hutan dengan peningkatan $\mathrm{pH}$ Saliva.

Sedangkan uji $\mathrm{T}$ menunjukkan hasil 2.063, dimana $\mathrm{T}$-value $=2.063$, berada pada nilai kritis 2.063 pada taraf sig. 95\% (Lower-Upper= 0.2349-0.4050), maka tidak terdapat perbedaan perubahan $\mathrm{pH}$ saliva sebelum dan setelah pemberian minuman madu hutan pada tingkat kepercayaan $95 \%$.

\section{PEMBAHASAN}

Hasil penelitian (pada tabel 5) menunjukkan bahwa nilai rata-rata $\mathrm{pH}$ saliva responden sebelum dan setelah pemberian minuman madu hutan mengalami penurunan atau tetap pada nilai asam dari 6.99 menjadi 6.67 Pada uji T dihasilkan nilai 2.063 dimana hal tersebut bermakna bahwa tidak terdapat perbedaan $\mathrm{pH}$ saliva sebelum dan setelah pemberian minuman madu hutan. Hasil uji korelasi dari pemberian minuman madu hutan terhadap perubahan $\mathrm{pH}$ saliva responden menunjukkan hasil 0.053 dimana hasil tersebut lebih besar daripada 0.05 sehingga $\mathrm{HO}$ ditolak dan Ha diterima, yang bermakna bahwa titidak terdapat pengaruh pemberian minuman madu dengan perubahan $\mathrm{pH}$ saliva responden. Hasil uji statistik tersebut dapat diinterpretasikan bahwa tidak terdapat perubahan $\mathrm{pH}$ saliva sebelum dan setelah pemberian minuman madu hutan, tetapi pemberian madu hutan ada perbedaan signifikan menyebabkan perubahan $\mathrm{pH}$ responden, hal tersebut dibuktikan dengan nilai korelasi statistik yaitu 0.053 yang bernilai lebih besar daripada 0.05 .

Nilai rata-rata $\mathrm{pH}$ saliva responden mengalami penurunan namun tidak mencapai nilai $\mathrm{pH}$ kritis $(\mathrm{pH}<5.5)$. Hal ini cenderung berlawanan dengan teori yang diungkapkan oleh Stephan, bahwa 10 menit setelah konsumsi glukosa maka akan terjadi penurunan $\mathrm{pH}$ hingga mencapai nilai $\mathrm{pH}$ kritis $(\mathrm{pH}<5.5)$. (Dawes, 1996)

Perbedaan ini mungkin terjadi karena perlakuan yang dilakukan dalam penelitian ini sedikit berbeda dengan percobaan yang dilakukan oleh Stephan. Stephan melakukan percobaan dengan kumur glukosa 10\% sehingga didapatkan penurunan nilai $\mathrm{pH}$ plak mencapai 5.5 dalam waktu 10 menit setelah perlakuan. Sementara pada penelitian ini, subjek tidak berkumur melainkan hanya menahan selama 60 detik madu di dalam rongga mulut kemudian ditelan sehingga waktu pemaparan madu di dalam rongga mulut lebih singkat. Selain itu, pengukuran yang dilakukan bukan terhadap $\mathrm{pH}$ plak yang lebih stabil, melainkan terhadap $\mathrm{pH}$ saliva yang mudah berubah. Dengan demikian, mungkin saja nilai $\mathrm{pH}$ saliva yang diberikan sudah dinetralkan oleh kerja kapasitas dapat saliva subjek dalam rentang waktu 10 menit sebelum dilakukannya pengukuran.

Hasil tersebut berbanding terbalik dengan penelitian yang dilakukan oleh Fione (2013) yang menunjukkan hasil peningkatan rata-rata nilai $\mathrm{pH}$ saliva responden dari 6.257 menjadi 7.043. Hal ini disebabkan karena di dalam madu terdapat kandungan mineral yang dapat meningkatkan produksi saliva atau cairan ludah sehingga dapat menjaga keseimbangan $\mathrm{pH}$ saliva di dalam rongga mulut. (Purbaya, 2007)

Namun penurunan nilai $\mathrm{pH}$ saliva menjadi lebih asam sesuai dengan hasil penelitian yang dilakukan oleh Dwi Eni Purwati (2016) yang menyatakan bahwa nilai $\mathrm{pH}$ saliva pada kelompok eksperimen sesudah mengkonsumsi minuman madu mengalami penurunan dari sebelum mengkonsumsi minuman madu, yaitu dari 6.93 menjadi 6.64 dengan nilai sig. 005, yang menunjukkan adanya perbedaan yang bermakna antara nilai $\mathrm{pH}$ saliva siswa siswi kelas III, IV dan V SD 
Muhammadiyah Sambisari sebelum dan sesudah mengkonsumsi minuman madu. Perbedaan ini disebabkan karena menurunnya nilai $\mathrm{pH}$ saliva siswa setelah mengkonsumsi minuman madu tetapi masih dalam standar normal nilai pH saliva yaitu 6.93 menjadi 6.64. Sesuai dengan hasil penelitian yang dilakukan oleh Sari (2008) yang menyatakan bahwa nilai $\mathrm{pH}$ rata-rata setelah mengkonsumsi madu menunjukkan adanya penurunan, yaitu dari 7.40 menjadi 6.94. Meskipun demikian, penurunan nilai $\mathrm{pH}$ ini ternyata tidak mencapai nilai $\mathrm{pH}$ kritis $(\mathrm{Ph}<5.5)$. Penurunan nilai $\mathrm{pH}$ ini dikarenakan setelah saliva terstimulasi oleh air madu, terjadi pemecahan karbohidrat menjadi asam laktat. Akibatnya, terjadi penurunan $\mathrm{pH}$ di dalam rongga mulut.

Faktor lainnya yang mungkin menyebabkan turunnya nilai $\mathrm{pH}$ saliva setelah mengkonsumsi madu adalah karena madu memiliki nilai $\mathrm{pH}$ yang asam. Menurut Putri (2014) nilai $\mathrm{pH}$ madu rata-rata adalah 3.2-4,5. Nilai $\mathrm{pH}$ madu yang cukup rendah ini disebabkan oleh beberapa kandungan asam organik yang terdapat dalam madu, seperti asam asetat, asam format, asam glukonat, asam oksalat, asam piroglutamat, asam suksinat, asam laktat, asam malat, asam glikolat, asam butirat, asam sitrat, asam piruvat dan asam tartrat. (Fione, dkk. 2013)

Namun penelitian ini didukung oleh Meily Zuraida (2007) yang dalam penelitiannya tentang perbedaan $\mathrm{pH}$ saliva terhadap konsumsi madu yang menunjukkan penurunan $\mathrm{pH}$ saliva dari 7.0 menjadi 6.8 dengan nilai kemaknaan sebesar 1,000 ( $p>0,05)$ yang artinya tidak ada hasil yang signifikan setelah mengkonsumsi madu, tetapi penurunan $\mathrm{pH}$ saliva tersebut tidak sampai mencapai titik kritis $(\mathrm{pH}<5,5)$. Artinya dalam penelitian ini kapasitas buffer responden masih efektif dan ditunjang oleh jumlah kuman yang berkurang.
Berdsarkan faktor-faktor di atas dapat dijelaskan bahwa konsumsi makanan atau minuman tertentu bukan menjadi satu-satunya faktor terjadinya perubahan $\mathrm{pH}$ saliva. Faktor yang menyebabkan terjadinya perubahan pada $\mathrm{pH}$ saliva antara lain rata-rata kecepatan aliran saliva, mikroorganisme rongga mulut dan kapasitas buffer saliva. Selain itu ada faktorfaktor yang mempengaruhi pembentukan asam, antara lain: jenis karbohidrat yang terdapat dalam diet, konsentrasi karobohidrat dalam diet, jenis dan jumlah bakteri di dalam plak, keadaan fisiologi bakteri tersebut dan $\mathrm{pH}$ di dalam plak.

Konsumsi obat-obatan tertentu serta ritme biologis tubuh juga perlu dikaji sebelum pengambilan sampel pada responden. Obatobatan antidepresan, antipsikotik, transquilizer, antihistamin, hipnotika, antihipertensi, antikholinergi, diuretika, antiparkinson, dan obat pengurang nafsu makan. Jika obat-obatan tersebut digunakan untuk waktu lebih dari satu minggu, maka harus diambil langkah-langkah untuk melindungi gigi dari serangan karies. (Edwina, 1991)

Dalam penelitian ini responden dengan usia antara 21-30 tahun memiliki rata-rata $\mathrm{pH}$ saliva 6.81 dan responden dengan usia antara 31-40 tahun memiliki rata-rata $\mathrm{pH}$ saliva 6.71. Artinya faktor umur juga berpengaruh dalam penurunan $\mathrm{pH}$ saliva. Keadaan ini disebabkan oleh adanya perubahan atropi pada kelenjar saliva sesuai dengan pertambahan umur yang akan menurunkan produksi saliva dan mengubah komposisinya sedikit. Seiring dengan meningkatnya usia, terjadi proses aging. Terjadi perubahan dan kemunduran fungsi kelenjar saliva, dimana kelenjar parenkim hilang yang digantikan oleh jaringan lemak dan penyambung, lining sel duktus intermediate mengalami atropi. Keadaan ini mengakibatkan pengurangan jumlah aliran saliva. (Edwina, 1991) 
Selain itu latar belakang pendidikan atau pengetahuan responden tentang kesehatan gigi dan mulut juga menjadi salah satu faktor yang harus diperhatikan. Responden dalam penelitian ini adalah mahasiswa Jurusan Keperawatan Gigi yang memiliki pengetahuan yang baik tentang oral hygiene. Hal ini sesuai pendapat Notoatmodjo (2005) yang mengatakan tingkat pengetahuan akan mempengaruhi tingkat penguasaan responden terhadap derajat kesehatannya, karena dalam pendidikan terjadi proses pembelajaran yang selanjutnya akan mempengaruhi perilaku seseorang dalam melakukan tindakan pemeliharaan dan peningkatan kesehatan.

\section{KESIMPULAN}

Berdasarkan hasil penelitian yang telah dilakukan pada 25 responden tentang pengaruh konsumsi minuman madu hutan terhadap tingkat keasaman $\mathrm{pH}$ saliva pada perawat Instalasi Bedah Sentral (IBS) Di RSUD Labuang Baji Makassar, dapat disimpulkan bahwa:

1. Tidak terdapat pengaruh konsumsi minuman madu hutan terhadap $\mathrm{pH}$ saliva setelah pemberian minuman madu hutan.

2. Rata-rata tingkat keasaman $\mathrm{pH}$ saliva sebelum mengkonsumsi minuman madu hutan adalah 6.99 dan setelah mengkonsumsi minuman madu hutan adalah 6.67 .

\section{SARAN}

1. Meskipun tidak terdapat pengaruh antara konsumsi minuman madu hutan terhadap $\mathrm{pH}$ saliva, namun disarankan untuk tetap berkumur air putih setelah mengkonsumsi minuman madu hutan dan minuman/makanan manis lainnya.

2. Perlu diadakan penelitian lebih lanjut dari penelitian di atas dengan jumlah sampel yang lebih banyak.

\section{DAFTAR PUSTAKA}

Aden, R. 2010. Manfaat \& Khasiat Madu Keajaiban Sang Arsitek Alam. Yogyakarta: Hanggar Kreator

Amerongen A van Nieuw. 1991. Ludah dan Kelenjar Ludah. Alih Bahasa. Abyo R. Gadjah Mada University Press. Yogyakarta

Dawes C. 1996. Factors Influencing Salivary Flow Rate And Composition. In Edgar WM. O'Mullane DM (ed). Saliva and Oral Health. 2nd ed. London: British Dental Association.

Edwina A.M, Joyston B.S. Dasar-dasar karies penyakit dan penanggulangannya. Editor: Narlan Sumawinata, Safrida Faruk. Jakarta: EGC; 1991.

Faisol Al Fady. 2015. Madu dan Luka Diabetik. Gosyen Publishing. Yogyakarta

Fione, Roose, V., Maramis, J.L, dan Meylandri, D.P., 2013. Pengaruh Berkumur Dengan Larutan Madu Terhadap pH Saliva Pada Wanita Kaum Ibu Jemaat Getsemani Desa Senduk Kecamatan Tombariri. Jurnal Jurusan Keperawatan Gigi Poltekkes Kemenkes Manado JIK. 7(2)

Firdaus Chandra. 2006. Pengaruh stimulus pengunyahan dan pengecapan terhadap kecepatan aliran dan $\mathrm{pH}$ saliva. Fakultas Kedokteran Gigi Universitas Hasanuddin Makassar.

Garant, Philias R. 2003. Oral Cell and Tissues. Qiuntessence Publishing Co.

Haviva, A.B. 2011. Dahsyatnya Mukjizat Madu untuk Kesehatan, Kecantikan dan Kecerdasan. Jogjakarta: DIVA Press.

Ilyas M., Yusri M. 2007. Perbedaan kadar kalsium dalam saliva sebelum dan sesudah mengkonsumsi minuman ringan yang mengandung asam bikarbonat. Jurnal Kedokteran Gigi vol. 16 no. 2

Intanwidya, Y. 2005. Analisa Madu dari Segi Kandungannya Berikut Khasiatnya Masing-Masing. [Online] Available from: http://www.mailarchive.com/forum@alumniakabogor.net/msg01046.html. Accessed September.

Joshi SR, Pechhacker H, William A, Von der Ohe W. 1999. Phisico-Chemical Characteristics of Apis dorsata, A.cerana, and A. Mallifera honey. Hal. 2000.

Lugaz O, Phillias AM, Boireau-Ducept $\mathrm{N}$ and Faurion A. 2005. Time-Intensity Evaluation of Acid Taste in Subjects with Saliva High Flow and Low Flow Rates for Acids of Various Chemical Properties. Chemical Sence. 30(1). 
Minasari. 1999. Peranan saliva dalam rongga mulut. Majalah Kedokteran Gigi Universitas Sumatera Utara.

Molan PC. 2001. The potential of honey to promote oral wellness. Gen Dent. NovDec: (49) 6.

Namias, N. 2003. Honey in The Management of Infection. Miami: De Witt Dughtry Family Department of Surgery, University Scholl of Medicine.

Nanci A. 2008. Ten cate's oral Hystology: development, structure, and function. St. Louis : Mosby Elsevier

Navazesh M, Kumar SK. 2008. Measuring salivary flow: challenges and opportunities. J Am Dent Assoc

Notoatmodjo, s, 2005, Promosi kesehatan teori dan Aplikasi, Jakarta : PT Rineka Cipta

Republika online. 2018. Madu untuk Sakit Tenggorok. [Online] Available from: http://www.republika.co.id. Accessed September.

Sari, C.P. 2018. Perbandingan Nilai Viskositas, pH dan Kapasitas Dapar Saliva Setelah Mengkonsumsi Air Madu Dan Air Gula Sukrosa. Skripsi Program Studi Kedokteran Gigi Universitas Indonesia. Jakarta.

Wirakusumah PA. 2010. Sehat Cara Al-Qur'an dan Hadist. Penerbit Hikmah. Bandung.

Wong DT. 2008. Salivary Diagnostic. Iowa: Wiley-Blackwell

Zuraida Meily. 2007. Perbedaan pH saliva terhadap konsumsi madu dan permen coklat. Fakultas Kedokteran Gigi Universitas Hasanuddin Makassar.

Faizalnizbah online. 2015. Sejarah rumah sakit labuang baji. Available from: http://faizalnizbah.blogspot.com 